University of Nebraska - Lincoln

DigitalCommons@University of Nebraska - Lincoln

Publications from USDA-ARS / UNL Faculty

U.S. Department of Agriculture: Agricultural

Research Service, Lincoln, Nebraska

1999

\title{
Chlorophyll Meter as Nitrogen Management Tool in Malting Barley
}

Brian J. Wienhold

University of Nebraska-Lincoln, Brian.Wienhold@ars.usda.gov

J. M. Krupinsky

USDA-ARS

Follow this and additional works at: https://digitalcommons.unl.edu/usdaarsfacpub

Wienhold, Brian J. and Krupinsky, J. M., "Chlorophyll Meter as Nitrogen Management Tool in Malting Barley" (1999). Publications from USDA-ARS / UNL Faculty. 1192.

https://digitalcommons.unl.edu/usdaarsfacpub/1192

This Article is brought to you for free and open access by the U.S. Department of Agriculture: Agricultural Research Service, Lincoln, Nebraska at DigitalCommons@University of Nebraska - Lincoln. It has been accepted for inclusion in Publications from USDA-ARS / UNL Faculty by an authorized administrator of DigitalCommons@University of Nebraska - Lincoln. 
COMMUN. SOIL SCI. PLANT ANAL., 30(17\&18), 2551-2562 (1999)

\title{
Chlorophyll Meter as Nitrogen Management Tool in Malting Barley'
}

\author{
Brian J. Wienhold ${ }^{a}$ and J. M. Krupinsky ${ }^{b}$ \\ ${ }^{a} U S D A-A R S-S W C R U, 2119$ Keim Hall, East Campus, University of Nebraska, \\ Lincoln, NE 68583 \\ bUSDA-ARS-NGPRL, P.O. Box 459, Mandan, ND 58554
}

\begin{abstract}
Variable precipitation in many regions makes it difficult to predict yield goals and nitrogen $(\mathrm{N}$ ) rates for malting grade barley (Hordeum vulgare $\mathrm{L}$.). During years with below normal growing season precipitation, barley fertilized at the recommended rate often exhibits grain protein concentrations exceeding what is acceptable for malting. A study was conducted to evaluate the chlorophyll meter as a $\mathrm{N}$ management tool. Barley was grown under several $\mathrm{N}$ rates in the field. Chlorophyll meter readings and $\mathrm{N}$ additions were made at the Haun 4 to 5 growth stage, and grain yield and protein concentrations were evaluated at maturity. Chlorophyll meter readings, normalized as meter reading from treatment plot divided by that from a plot receiving a full $\mathrm{N}$ treatment at the Haun 4 to 5 growth stage, were correlated with grain yield
\end{abstract}

${ }^{1}$ Mention of trade names or proprietary products does not indicate endorsement by USDA and does not imply its approval to the exclusion of other products that may be suitable. ${ }^{2}$ The U.S. Department of Agriculture offers its programs to all eligible persons regardless of race, color, age, sex, or national origin and is an equal opportunity employer.

Copyright $(\mathcal{O} 1999$ by Marcel Dekker, Inc.

www.dekker.com

This article is a U.S. government work, and is not subject to copyright in the United States. 
$\left(\mathrm{r}^{2}=0.67\right)$. Stands having normalized chlorophyll meter readings below $95 \%$ responded to $\mathrm{N}$ additions with yields equivalent to the fully fertilized stand and grain protein concentrations acceptable for malting. A $\mathrm{N}$ management strategy is proposed whereby 40 to $50 \%$ of the $N$ calculated for the yield goal is applied at planting and a fully fertilized reference strip is included for each variety or soil type. At the Haun 4 to 5 growth stage, chlorophyll meter readings are taken in the reference strip and in the field. Normalized chlorophyll meter readings below $95 \%$ of the reference strip indicate a need for additional $\mathrm{N}$ fertilizer. This strategy will provide producers with additional time (up to a month) to evaluate growing season conditions before investing in additional crop inputs and will improve the likelihood that a barley crop acceptable for malting will be produced.

\section{INTRODUCTION}

Nitrogen is the plant nutrient most often limiting cereal crop production and is the fertilizer nutrient applied in largest amounts by producers in the United States. Cereal crops typically respond to $N$ rates with yield and quality increasing until a plateau is reached. For many cereal crops, higher quality (especially protein) grain has special uses and often command a premium price. Based on yields, fertilizer costs, and crop prices, economic and agronomic fertilizer rates can be calculated. For many crops, the cost associated with over fertilizing with $\mathrm{N}$ is low compared to the potential loss associated with lower yield or lower quality resulting from under fertilization. In contrast, a few crops such as potato (Solanum tuberosum $\mathrm{L}$.), sugar beet (Beta vulgaris $\mathrm{L}$.), and malting barley (Hordeum vulgare L.) exhibit reduced yields with ins afficient $\mathrm{N}$, and reduced yields or quality with excessive $\mathrm{N}$ (Kleinkopf et al., 198; ; Halvorson et al., 1978; Weston et al., 1993). For these crops, $\mathrm{N}$ management is especially important.

Precipitation in many barley producing regions (e.g., Pacific Northwest and Northern Great Plains) is highly variable. Barley yields are highly dependent on soil water present at seeding and precipitation received during the growing season. High variability in precipitation and resultant variability in yields make it difficult to estimate a yield goal when calculating $\mathrm{N}$ fertilizer needs. Water and $\mathrm{N}$ availability influence grain yield and protein concentration (Banasik and Power, 1973). Barley grain protein concentrations must be between 100 and $125 \mathrm{~g} \mathrm{~kg}^{-1}$ for 2-row varieties and between 105 and $135 \mathrm{~g} \mathrm{~kg}^{-1}$ for 6-row varieties to be acceptable for malting. Years with above normal precipitation often result in high yields, but unacceptably low protein concentrations. Conversely, years with below normal precipitation often result in low yields with excessively high protein concentrations. Improved methods for determining fertilizer $\mathrm{N}$ requirements in malting barley during the growing season are needed.

The Minolta SPAD 502 chlorophyll meter has been used to assess the $\mathrm{N}$ status of crops. Several researchers have used this meter to compare cereal crop N 
status in $\mathrm{N}$ fertility trials and have demonstrated that the meter is capable of discriminating among $\mathrm{N}$ treatments (Turner and Jund, 1991; Follett et al., 1992; Wood et al., 1992; Fox et al., 1994; Smeal and Zhang, 1994). Few studies have been undertaken to use the chlorophyll meter to identify underfertilized stands and evaluate the response of these stands to $\mathrm{N}$ applications made during the growing season. Turner and Jund (1991) fertilized one-half of paired plots in a semidwarf rice (Oryza sativa $\mathrm{L}$.) $\mathrm{N}$ fertility trial and found that this crop would respond to $\mathrm{N}$ additions during the season, and that the chlorophyll meter could potentially identify underfertilized stands. Peng et al. (1995) related chlorophyll meter readings to leaf $\mathrm{N}$ concentration expressed on an areal basis $\left(\mathrm{kg} \mathrm{N} \mathrm{m}^{-2}\right)$ and found that the regression was similar among varieties and sampling times at their location. Later work used this regression to identify rice stands having $\mathrm{N}$ concentrations below the critical level required to optimize yield (Peng et al., 1996). Fertilization of rice stands, identified using the chlorophyll meter as having leaf $\mathrm{N}$ concentrations below the critical level, resulted in lower $\mathrm{N}$ inputs, similar yields, and higher $\mathrm{N}$ use efficiency than in stands fertilized using traditional guidelines (Peng et al., 1996). Piekielek and Fox (1992) concluded that the chlorophyll meter could accurately separate corn (Zea mays $\mathrm{L}$.) stands that would respond to sidedress $\mathrm{N}$ applications from nonresponsive stands, but further research was needed to determine if specific sidedress $\mathrm{N}$ rates could be estimated. Blackmer and Schepers (1995) demonstrated that corn with adequate $\mathrm{N}$ early in the season that developed $\mathrm{N}$ deficiencies later in the season could be identified using a chlorophyll meter and could be fertigated without a loss in yield. A similar approach of applying $\mathrm{N}$ during the growing season has not been used on malting barley.

The objective of this study was to evaluate the chlorophyll meter as a $\mathrm{N}$ management tool in malting barley production by assessing the potential for using the chlorophyll meter to identify underfertilized stands, and determining the response of an underfertilized stand to $\mathrm{N}$ additions at the Haun 4 to 5 stage of growth (Haun, 1973). The Haun scale is a numerical scale based on the number of leaves and the sequence of leaf insertion on the main stem. A barley plant at the Haun 4 to 5 stage of growth would be a seedling with 4 or 5 fully expanded leaves. Delaying fertilizer decisions to this growth stage will provide producers with an additional month to evaluate current growing season conditions and allow topdressing $\mathrm{N}$ without damaging the crop during the application process.

\section{MATERIALS AND METHODS}

The field site was located in Morton County $6.4 \mathrm{~km}$ southwest of Mandan, ND. Soils at the site are a Temvik-Wilton silt loam (fine-silty, mixed Typic and Pachic Haploborolls). Annual precipitation is highly variable and averages $410 \mathrm{~mm}$ with $60 \%$ being received during the April to October growing season. Average annual temperature is $4^{\circ} \mathrm{C}$ and daily averages range from a maximum of $21^{\circ} \mathrm{C}$ during the summer to a minimum of $-11^{\circ} \mathrm{C}$ during the winter. 
Barley (var. 'Stander' in 1997 and 'Stander' and 'Foster' in 1998), was planted with a John Deere 750 drill on Me.y 16, 1997 and with a Haybuster 107 disk drill on May 18, 1998. 'Stander' is a high protein 6-rowed barley and 'Foster' is a low protein 6-rowed barley. The previous crop was sunflower (Helianthus annuus L.) each year. Barley was planted in plots having no tillage in 1997. Two tillage operations were performed with a John Deere Mulchmaster in 1998 to control weed growth prior to planting. Treatments were applied to plots ( 9 by $15 \mathrm{~m}$ ) arranged in a completely randomized blocks design with three replications. Residual $\mathrm{NO}_{3}-\mathrm{N}$ (0-to-60 cm depth) was $49 \mathrm{~kg} \mathrm{ha}^{-1}$ in 1997 and $27 \mathrm{~kg} \mathrm{ha}^{-1}$ in 1998. All treatments received $11-52-0$ fertilizer $\left(10.1 \mathrm{~kg} \mathrm{~N}^{-1}\right.$ in 1997 and $8.1 \mathrm{~kg} \mathrm{~N}$ $\mathrm{ha}^{-1}$ in 1998) with the seed at planling. The remaining $\mathrm{N}$ was surface applied. In $1997, \mathrm{~N}$ as $\mathrm{NH}_{4} \mathrm{NO}_{3}$ was applied to three plots at 0,36 , and $72 \mathrm{~kg} \mathrm{~N} \mathrm{ha}{ }^{-1}$. An additional two plots received $36 \mathrm{~kg} \mathrm{~N} \mathrm{ha}^{-1}$ preplant and either 18 or $36 \mathrm{~kg} \mathrm{~N}^{-1}$ at the Haun 4 to 5 growth stage. Based on 1997 yields, the 1998 yield goal was increased and $\mathrm{N}$ rates were adjusled to meet the higher yield goal. In 1998, $\mathrm{N}$ treatments were the same for both varieties. Urea $\mathrm{N}$ was applied to four plots at 0 , 56,85 , and $113 \mathrm{~kg} \mathrm{~N} \mathrm{ha}^{-1}$. An additional two plots received $56 \mathrm{~kg} \mathrm{~N} \mathrm{ha}^{-1}$ preplant as urea and either 21 or $42 \mathrm{~kg} \mathrm{Nha}^{-1}$ at the Haun 4 to 5 growth stage as $\mathrm{NH}_{4} \mathrm{NO}_{3}$. In both years, plots receiving all $\mathrm{N}$ preplant provided information on the response of yield and grain protein concentration to $\mathrm{N}$ rate. The plots receiving a split $\mathrm{N}$ application provided information on the potential for modifying grain yield and protein concentration through $\mathrm{N}$ management during the growing season.

When the crop was at the Haun 4 to 5 growth stage, a chlorophyll meter reading was taken midway on the fourth leaf (15 per plot in 1997 and 20 per plot in 1998). In 1997, the entire seedling was collected for $N$ determination, and in 1998, only the fourth leaf was collected for $\mathrm{N}$ determination. Five additional plants from each plot were collected in both years, the emerging heads were removed from the sheath, placed in preservative solution, returned to the lab, and the number of spike primordia determined. At maturity, all aboveground biomass was collected from 47 by $94 \mathrm{~cm}$ quadrates (three per plot in 1997, five per plot in 1998), dried at $70^{\circ} \mathrm{C}$, and threshed. The grain vas weighed and a subsample ground to pass a $0.5 \mathrm{~mm}$ sieve for $\mathrm{N}$ determination. Grain yields were adjusted to $125 \mathrm{~g} \mathrm{~kg}^{-1}$ moisture. Plant leaf and grain $\mathrm{N}$ concentration was determined by dry combustion using a Carlo-Erba NA 1500 NCS analyzer.

\section{RESULTS AND DISCUSSION}

Nitrogen concentration at the Hz.un 4 to 5 growth stage varied among varieties and years (Figure 1). Variation among chlorophyll meter readings within a plot was consistent (c.v. $=12 \%$ ). The annual and varietal variation in leaf $\mathrm{N}$ concentration resulted in three separate regression equations between leaf $\mathrm{N}$ concentration and chlorophyll meter readings. In 1997, chlorophyll meter readings 


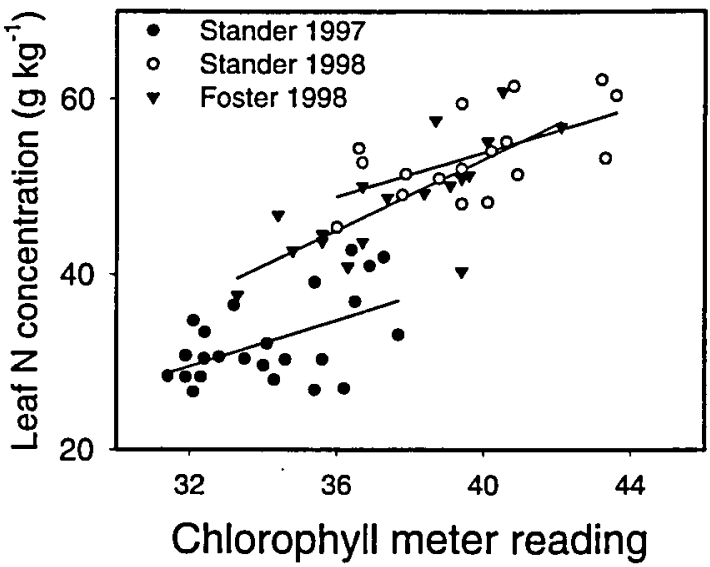

FIGURE 1. Relationship between chlorophyll meter readings and tissue $\mathrm{n}$ concentration in barley.

were taken on the fourth leaf and the entire seedling was collected and analyzed for $\mathrm{N}$ concentration. In 1998, chlorophyll meter readings were taken on the fourth leaf and only that leaf blade was collected and analyzed for $\mathrm{N}$ concentration. This difference in sampling strategies likely explains the lower $\mathrm{N}$ concentrations for 1997 (lower $N$ concentration for whole plant vs. $N$ concentration of leaf blade) and the improvement in the fit of the regression lines in $1998\left(r^{2}=0.35\right.$ for 'Stander' and 0.57 for 'Foster') when compared to the fit of the regression line in 1997 $\left(r^{2}=0.28\right)$. Others have reported on site and varietal differences in the relationship between chlorophyll meter readings and tissue $\mathrm{N}$ concentration (Follett et al., 1992; Piekielek and Fox, 1992; Schepers et al., 1992).

The number of spikelet primordia which had formed by the Haun 4 to 5 growth stage was greater in $1998(89.4 \pm 0.6)$ than in $1997(62.4 \pm 1.2)$. There were no differences among varieties or $\mathrm{N}$ treatments in spikelet primordia numbers. Spikelet development was slightly more advanced in 1998 than in 1997. Barley does not produce a terminal spikelet until awns begin to form (Al Frank, USDAARS, Mandan, ND, personal communication). In 1997, awns were not apparent and a terminal spikelet may not have been formed at the time of sampling. In 1998, awns were apparent and spikelet primordia production was likely complete at the time of sampling. Spikelet primordia numbers at the Haun 4 to 5 growth stage were to be used as an estimate of potential yield. The relationship between spikelet primordia numbers at the Haun 4 to 5 growth stage and yield over the two years of this study was poor (spikelet primordia numbers were greater in 1998 than in 1997 while yields were greater in 1997 than in 1998). Additional research 
is needed to develop a sampling piotocol and determine the relationship between spikelet primordia numbers and yield potential in barley. Several other stand characteristics influence yield (e.g., plant density, number of tillers, spikelet numbers, kernels per spike) and a reliable estimate of yield may be difficult to obtain at such an early growth stage (Bauer et al., 1990).

Grain yield in plots receiving preplant $\mathrm{N}$ exhibited a typical response to $\mathrm{N}$ rate for 'Stander' in 1997 (Figure 2A) and 'Foster' in 1998 (Figure 2C). 'Stander' grain yields in 1998 did not respond to N-rate (Figure 2B). Barley in plots receiving a split application of $\mathrm{N}$ in 1997 exhibited yields similar to those in plots receiving preplant N (Figure 2A). In 1998, the split application reduced grain yields slightly (Figure 2B and C). Soil moisture at seeding was near field capacity in 1997, and this combined with timely rains during the growing season resulted in near optimum yields that year. Below normal winter precipitation resulted in low soil moisture levels at seeding in 1998. The tillage needed to control weeds prior to planting likely exacerbated these low soil moisture levels. Below normal growing season precipitation (70\% of average) and dry conditions at planting resulted in reduced barley yields in 1998. In 1998, the split $\mathrm{N}$ application at the Haun 4 to 5 growth stage likely stimulated vegetative growth when compared to plots receiving $\mathrm{N}$ preplant. This stimulation in vegetative growth likely resulted in an increase in water use and greater water stress during the grain filling period lowering yields in these plots (van Keulen, 1981). Luebs and Laag (1969) reported a similar response where straw production in plots receiving $90 \mathrm{~kg} \mathrm{~N} \mathrm{ha}^{-1}$ was greater $(4,580$ $\left.\mathrm{kg} \mathrm{ha}^{-1}\right)$ than in plots receiving $45 \mathrm{~kg} \mathrm{~N} \mathrm{ha}^{-1}\left(4,400 \mathrm{~kg} \mathrm{ha}^{-1}\right)$, but grain production was greatly reduced ( $680 \mathrm{vs} 2,600 \mathrm{~kg} \mathrm{ha}^{-1}$ ) in fields with limited available water.

Grain protein in plots receiving $\mathrm{N}$ preplant increased linearly with $\mathrm{N}$ rate for 'Stander' in 1997 (Figure 3A) and at the highest $N$ rate had protein concentrations within the range acceptable for malting barley. In 1997, 'Stander' plots receiving a split application of $\mathrm{N}$ had grain protein concentrations that were higher than in plots receiving all $\mathrm{N}$ preplant (Figure $3 \mathrm{~A}$ ) and at the highest $\mathrm{N}$ rate had protein concentrations within the range acceptable for malting barley. In 1998, 'Stander' grain protein concentration in all plots receiving $\mathrm{N}$ preplant exceeded acceptable levels for malting barley (Figure 3Ei). In 1998, 'Foster' grain protein concentration in all plots receiving $\mathrm{N}$ preplant were within the range of protein concentrations acceptable for malting barley (Figure 3C). In 1998, 'Stander' and 'Foster' grain protein concentrations were lower in plots receiving a split application of $\mathrm{N}$ than in plots receiving $\mathrm{N}$ preplant (Figure $3 \mathrm{~B}$ and $\mathrm{C}$ ).

The yearly and varietal variation in chlorophyll meter readings limits the usefulness of these readings as predictors of grain yield or protein. Yearly and varietal variation can often be overcome by normalizing chlorophyll meter readings to an adequately fertilized reference stand (Blackmer and Schepers, 1995). Chlorophyll meter readings for this study were normalized by dividing chlorophyll meter readings from each of the $\mathrm{N}$ rate treatments by the chlorophyll meter reading 


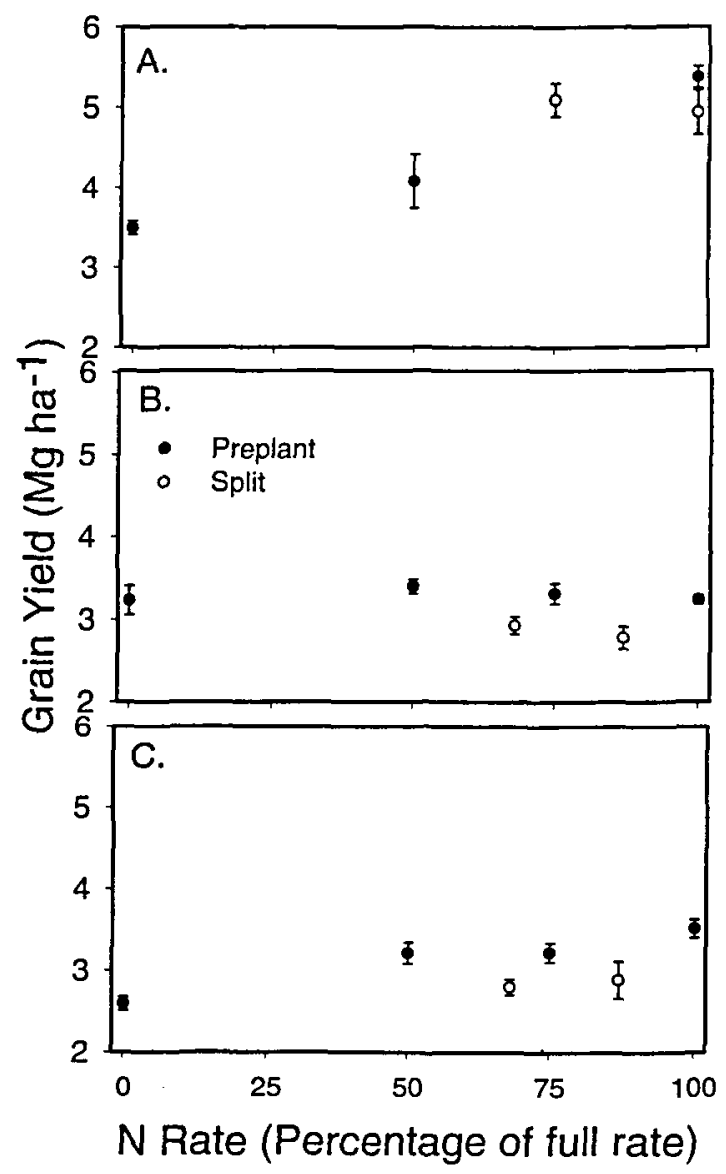

FIGURE 2. Barley grain yield as a function of $\mathrm{N}$ rate and timing of application for $\mathrm{A}$ ) Stander 1997, B) Stander 1998, and C) Foster 1998.

of the full $\mathrm{N}$ treatment for that variety and year. Normalized chlorophyll meter readings for both varieties and both years were pooled and found to relate well with grain yield $\left(r^{2}=0.67\right)$, but not as well with grain protein $\left(r^{2}=0.23\right)$ (Figure 4).

Normalized chlorophyll meter readings appear to have potential for $\mathrm{N}$ management in malting barley. Providing 40 to $50 \%$ of the $\mathrm{N}$ needed to achieve the yield goal at planting and including a fully fertilized reference for each variety would allow use of a chlorophyll meter to determine if additional $\mathrm{N}$ was needed. In years when soil moisture is adequate, additional $\mathrm{N}$ will likely be needed to 


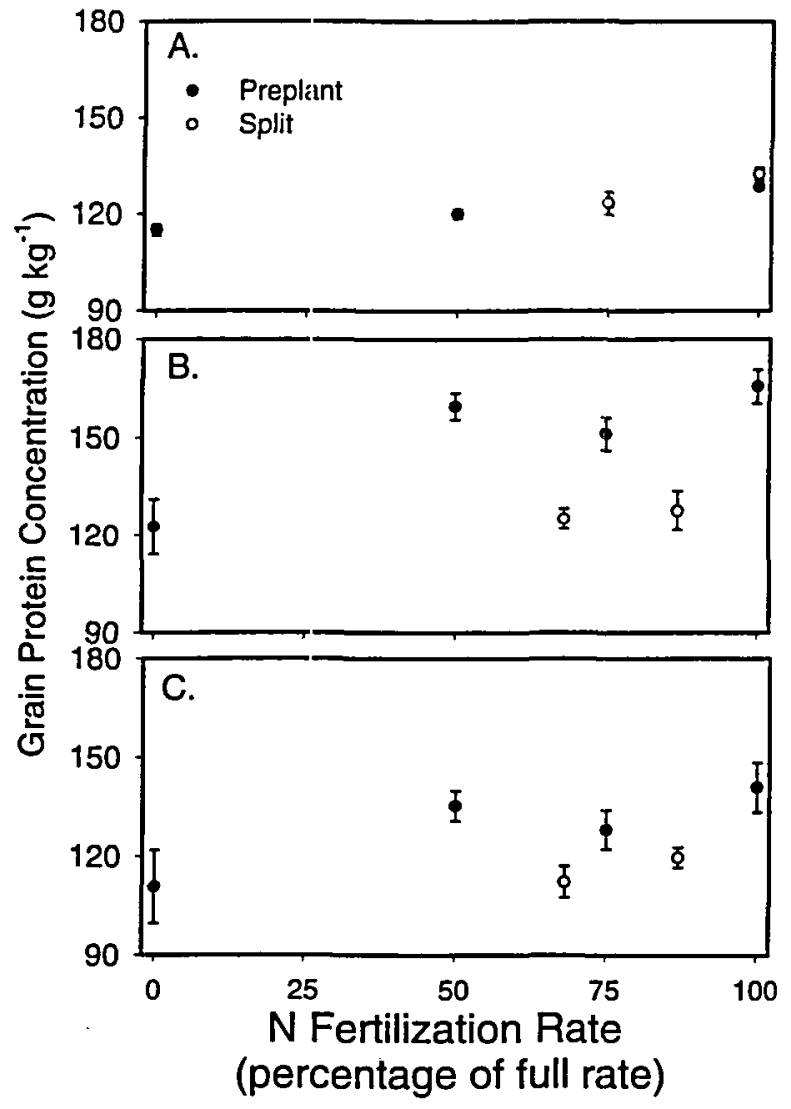

FIGURE 3. Barley grain protein concentration as a function of $\mathrm{N}$ rate and timing of application for A) Stander 1997, B) Stander 1998, and C) Foster 1998.

meet the yield goal and insure that adequate protein levels are achieved. At the Haun 4 to 5 growth stage, topdressing fields having a normalized chlorophyll meter reading below 95 would improve the chances that the barley crop would make malting grade. In 1997 (a year with adequate soil moisture), plots receiving $100 \%$ of the required $\mathrm{N}$ preplant had the highest yields $\left(5.38 \mathrm{Mg} \mathrm{ha}^{-1}\right)$ and a grain protein concentration (129 $\left.\mathrm{g} \mathrm{kg}^{-1}\right)$ acceptable for malting. Plots receiving $50 \%$ of the required $\mathrm{N}$ preplant had a relative chlorophyll meter reading of $94 \%$. Applying the remaining $50 \%$ of the $\mathrm{N}$ at the Haun 4 to 5 growth stage resulted in a yield of $4.94 \mathrm{Mg} \mathrm{ha}^{-1}$ ( $92 \%$ of the full $\mathrm{N}$ treatment) with a grain protein concentration (133 $\mathrm{g} \mathrm{kg}^{-1}$ ) acceptable for malting. The $8 \%$ yield reduction observed in 1997 was not statistically significant. 

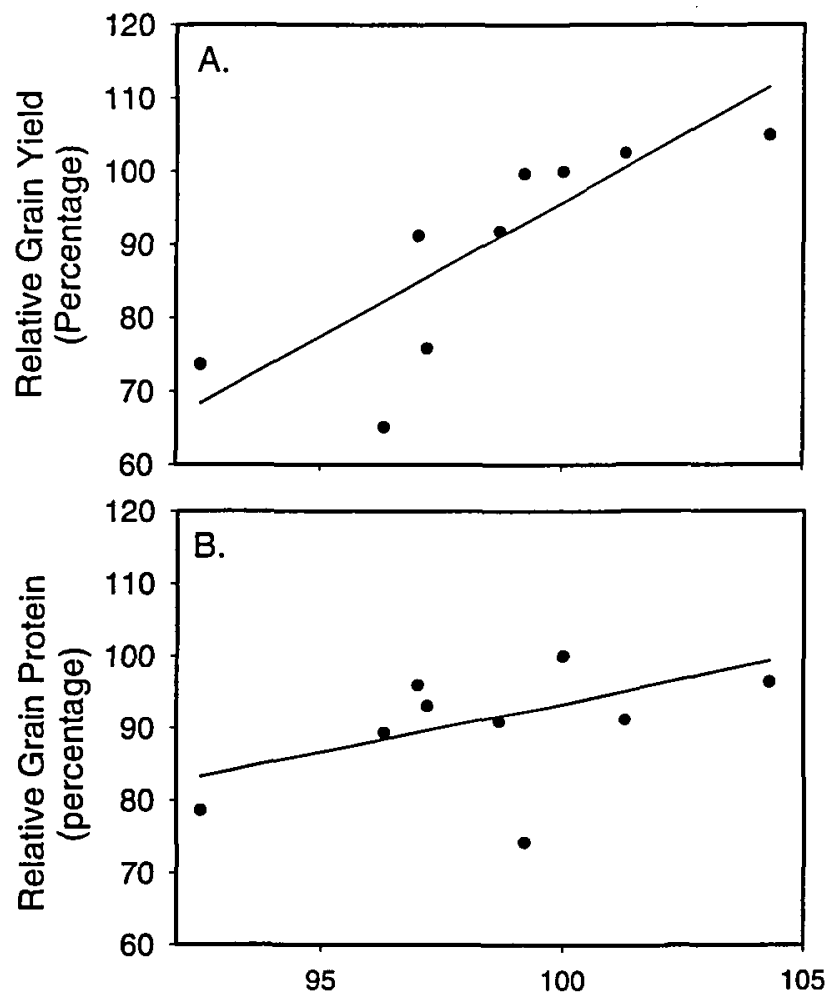

Relative Chlorophyll Meter Reading

FIGURE 4. Relationship between normalized chlorophyll meter readings and A) normalized yields and $B$ ) normalized grain protein concentrations.

In years where available moisture is below normal, barley yields are typically reduced and grain protein often exceeds that suitable for malting. In 1998 (a year with below normal soil moisture), 'Stander' plots receiving $50 \%$ of the required preplant $\mathrm{N}$ had relative chlorophyll meter readings above $95 \%$ at the Haun 4 to 5 growth stage. Grain from plots receiving $50 \%$ or more of the required $\mathrm{N}$ preplant had grain protein concentrations ( 151 to $166 \mathrm{~g} \mathrm{~kg}^{-1}$ ) that exceeded that acceptable for malting barley. In 1998, 'Foster' plots receiving $50 \%$ of the required N preplant had relative chlorophyll meter readings of $97 \%$ at the Haun 4 to 5 growth stage with grain yields of $3.21 \mathrm{Mg} \mathrm{ha}^{-1}$ ( $97 \%$ of plots receiving all $\mathrm{N}$ preplant) and grain protein concentrations ( $\left.135 \mathrm{~g} \mathrm{~kg}^{-1}\right)$ acceptable for malting. Grain from 'Foster' plots receiving $100 \%$ of the required $\mathrm{N}$ preplant had grain protein concentration (141 $\left.\mathrm{g} \mathrm{kg}^{-1}\right)$ that were higher than what is acceptable for malting barley. In years 
of below normal precipitation, even low protein barley varieties accumulate unacceptably high protein concentrations. As noted earlier, applying additional $\mathrm{N}$ at the Haun 4 to 5 growth stage reduced yields and protein concentrations in both varieties in 1998 .

These results suggest that in years with adequate soil moisture, the proposed $\mathrm{N}$ management strategy would result in yields of barley suitable for malting similar to those of a crop fully fertilized at planting. In years where insufficient soil moisture was available to the crop, $\mathrm{N}$ status (measured with a chlorophyll meter) at the Haun 4 to 5 growth stage was similar to that of a fully fertilized plot suggesting that no additional $\mathrm{N}$ is needed. In a dry year, applying $50 \%$ of the $\mathrm{N}$ calculated for the yield goal at planting may result in excessively high grain protein concentrations in high protein varieties. Further research is needed to determine $\mathrm{N}$ needs from seeding to the Haun 4 to 5 growth stage. In addition, further research is needed to determine the grain yield and protein concentration response to $\mathrm{N}$ rate applied at the Haun 4 to 5 growth stage.

\section{CONCLUSIONS}

A N management strategy is proposed for malting grade barley whereby 40 to $50 \%$ of the $\mathrm{N}$ calculated as necessary for the yield goal is applied at planting. A fully fertilized reference strip (fertilized at the rate recommended for the maximum potential yield) is included for each variety or soil type. At the Haun 4 to 5 growth stage, chlorophyll meter readings are taken in the reference strip and in the field. Relative chlorophyll meter readings below $95 \%$ of the reference strip indicate a need for additional fertilizer. Further research is needed to determine the minimum amount of $\mathrm{N}$ that is needed at planting to prevent yield reductions and that will minimize the chances of excessive grain protein concentrations during years when inadequate soil moisture is present. The proposed $\mathrm{N}$ management strategy will provide producers with additional time (up to a month) to evaluate growing season conditions before investing in additional crop inputs and improve the likelihood that a barley crop acceptable for malting will be produced.

\section{ACKNOWLEDGMENTS}

We thank the North Dakota Area IV Soil Conservation Districts for leasing the study site and Gary Brucker, John Bullinger, Jim Harms, Marv Hatzenbuhler, Larry Renner, and Mary Kay Tokach for field and laboratory assistance.

\section{REFERENCES}

Banasik, O.J. and J.F. Power. 1973. Effect of water and nitrogen supply on malting quality of barley. Brewers Dig. 48:56, 58-62. 
Bauer, A., A.L. Black, A.B. Frank, and E.H. Vasey. 1990. Agronomic characteristics of spring barley in the Northern Great Plains. North Dakota Agric. Exp. Stn. (Fargo) Bull. 532.

Blackmer, T.M. and J.S. Schepers. 1995. Use of a chlorophyll meter to monitor nitrogen status and schedule fertigation for corn. J. Prod. Agric. 8:56-60.

Follett, R.H., R.F. Follett, and A.D. Halvorson. 1992. Use of a chlorophyll meter to evaluate the nitrogen status of dryland winter wheat. Commun. Soil Sci. Plant Anal. 23:687-697.

Fox, R.H., W.P. Piekielek, and K.M. Macneal. 1994. Using a chlorophyll meter to predict nitrogen fertilizer needs of winter wheat. Commun. Soil Sci. Plant Anal. 25:171-181.

Halvorson, A.D., G.P. Hartman, D.F. Cole, V.A. Haby, and D.E. Baldridge. 1978. Effect of $\mathrm{N}$ fertilization on sugarbeet crown tissue production and processing quality. Agron. J. 70:876-880.

Haun, J.R. 1973. Visual quantification of wheat development. Agron. J. 65:116-119.

Kleinkopf, G.E., D.T. Westermann, and R.B. Dwelle. 1981. Dry matter production and nitrogen utilization by six potato cultivars. Agron. J. 73:799-802.

Luebs, R.E. and A.E. Laag. 1969. Evapotranspiration and water stress of barley with increased nitrogen. Agron. J. 61:921-924.

Peng, S., F.V. Garcia, R.C. Laza, A.L. Sanico, R.M. Visperas, and K.G. Cassman. 1996. Increased $\mathrm{N}$-use efficiency using a chlorophyll meter on high-yielding irrigated rice. Field Crops Res. 47:243-252.

Peng, S., R.C. Laza, F.V. Garcia, and K.G. Cassman. 1995. Chlorophyll meter estimates leaf area-based nitrogen concentration of rice. Commun. Soil Sci. Plant Anal. 26:927935.

Piekielek, W.P. and R.H. Fox. 1992. Use of a chlorophyll meter to predict sidedress nitrogen requirements for maize. Agron. J. 84:59-65.

Schepers, J.S., D.D. Francis, M. Vigil, and F.E. Below. 1992. Comparison of corn leaf nitrogen concentration and chlorophyll meter readings. Commun. Soil Sci. Plant Anal. 23:2173-2187.

Smeal, D. and H. Zhang. 1994. Chlorophyll meter evaluation for nitrogen management in corn. Commun. Soil Sci. Plant Anal. 25:1495-1503.

Turner, F.T. and M.F. Jund. 1991. Chlorophyll meter to predict nitrogen topdress requirement for semidwarf rice. Agron. J. 83:926-928. 
van Keulen, H. 1981. Modeling the interaction of water and nitrogen. Plant Soil 58:205229.

Weston, D.T., R.D. Horsley, P.B. Schwartz, and R.J. Goos. 1993. Nitrogen and planting date effects on low-protein spring barley. Agron. J. 85:1170-1174.

Wood, C.W., D.W. Reeves, R.R. Duffield, and K.L. Edmisten. 1992. Field chlorophyll measurements for evaluation of corn nitrogen status. J. Plant Nutr. 15:487-500. 